\title{
Locally Advanced Basal Cell Carcinoma
}

National Cancer Institute

\section{Source}

National Cancer Institute. Locally Advanced Basal Cell Carcinoma. NCI Thesaurus. Code C156770.

A basal cell carcinoma that has spread from its original site of growth to nearby tissues or lymph nodes. 